\title{
PENGARUH PERBANDINGAN BERAT PADATAN DAN WAKTU REAKSI TERHADAP GULA PEREDUKSI TERBENTUK PADA HIDROLISIS BONGGOL PISANG
}

\author{
Sri Rahayu Gusmarwani*1, M. Sri Prasetyo Budi1, Wahyudi Budi Sediawan², \\ dan Muslikhin Hidayat ${ }^{2}$ \\ ${ }^{1}$ Grup Riset Energi Biofuel, STTNAS, Yogyakarta \\ Jalan Babarsari Depok Sleman Yogyakarta 55281 \\ ${ }^{2}$ Jurusan Teknik Kimia, Fakultas Teknik, Universitas Gajah Mada \\ Jalan Teknika Utara Bulak Sumur Yogyakarta \\ Email: gusmarwani@yahoo.com
}

\begin{abstract}
Abstrak
Bioetanol adalah salah satu bentuk energi terbarukan yang menjanjikan. Sumber energi bioetanol dapat berasal dari limbah pertanian yang jarang dimanfaatkan seperti bonggol pisang. Produksi bonggol pisang di Indonesia mencapai 107,5 Mton per tahun. Selulosa yang terkandung dalam bonggol pisang mencapai $58,89 \%$ dapat diubah menjadi etanol melalui proses biologi dan kimia (biokimia). Untuk mengubah selulosa menjadi glukosa (gula) diperlukan proses hidrolisis dengan bantuan asam, misalnya asam sulfat $\left(\mathrm{H}_{2} \mathrm{SO}_{4}\right)$, sedangkan untuk mengubah gula menjadi bioetanol dipergunakan ragi Saccharomyces cereviseae. Dalam makalah ini disampaikan pengaruh perbandingan berat padatan dan waktu hidrolisis terhadap glukosa yang terambil pada reaksi hidrolisis untuk mengubah selulosa pada bonggol pisang menjadi glukosa yang dilakukan pada suhu $120^{\circ} \mathrm{C}$. Satu liter aquades dan 10 $\mathrm{mL}$ larutan asam sulfat pekat ditambahkan pada padatan dengan perbandingan (padatan:air) yang bervariasi dari 1:6,25, 1:5,88, 1:5,55, 1:5,25, 1:5, 1:4,75, 1:4,54, dan 1:4,375. Selanjutnya campuran dipanaskan dalam autoclave sampai suhu yang diinginkan tercapai $\left(120^{\circ} \mathrm{C}\right)$ dan dijaga konstan. Sampel diambil sebanyak $6 \mathrm{~mL}$ setiap 10 menit sampai waktu 90 menit tercapai. Analisis glukosa yang terbentuk dilakukan dengan metode LaneEynon. Hasil glukosa yang paling baik sebesar $13,08 \mathrm{~g} / 100 \mathrm{~mL}$ didapatkan pada suhu $120^{\circ} \mathrm{C}$ dalam waktu 80 menit dengan perbandingan padatan:aquadest 1:5.
\end{abstract}

Kata Kunci: Bioetanol, bonggol pisang, hidrolisis

\begin{abstract}
One of the promising biofuel is bioethanol which can be produced from agricultural waste cellulosic biomass such as banana plant waste. Production of banana rhizome waste in Indonesia is about 107.5 Mton annually. Banana rhizome contains $58.89 \%$ cellulose material that can be processed to produce bioethanol through biological and chemical processes. Sulfuric acid can be used in hydrolysis of cellulose material in banana plant waste to produce sugars, and Saccharomyces cereviseae can be used to convert sugars into bioethanol. This paper presents the result of studies on effects of solid ratio and time in hydrolysis of banana plant waste to produce sugars at $120^{\circ} \mathrm{C}$. One litre of water and $10 \mathrm{~mL}$ of sulfuric acid was mixed with various weight of banana plant waste then heated in an autoclave. The liquid samples were taken at various time and its sugar contents were analyzed by Lane and Eynon Methode. The solid ratio was varied between 1:6.25, 1:5.88, 1:5.55, 1:5.25, 1:5, 1:4.75, 1:4.54, and 1:4.375 and the time was varied between 0 minute and 90 minutse with 10 minutes interval. The highest yield of glucose of $13.08 \mathrm{~g} / 100 \mathrm{~mL}$ was achieved in 80 minutes and $1: 5$ of solid ratio.
\end{abstract}

Keywords: Bioethanol, banana rhizome, hydrolysis

*korespondensi 


\section{Pendahuluan}

Salah satu permasalahan serius yang dihadapi oleh banyak negara saat ini adalah jumlah bahan bakar fosil yang sangat terbatas sementara kebutuhan terus meningkat. Di sisi lain pemanasan global yang diakibatkan oleh pemakaian bahan bakar fosil semakin terasa. Kedua hal ini mendorong dikembangkannya bahan bakar alternatif yang bersifat terbarukan dan konservasi energi. Salah satu bentuk dari energi terbarukan adalah energi biomassa. Energi biomassa berasal dari bahan organik dan sangat beragam jenisnya. Sumber energi biomassa dapat berasal dari tanaman perkebunan atau pertanian, hutan, atau bahkan limbah, baik limbah domestik maupun limbah pertanian.

Biomassa dapat digunakan untuk sumber energi langsung maupun dikonversi menjadi bahan bakar. Penggunaan biomassa sebagai sumber energi ini tidak akan menyebabkan terjadinya penumpukan gas $\mathrm{CO}_{2}$ karena gas $\mathrm{CO}_{2}$ yang dihasilkan oleh reaksi pembakaran dipakai untuk pembentukan biomassa itu sendiri. Teknologi pemanfaatan energi biomassa yang telah dikembangkan terdiri dari pembakaran langsung dan konversi biomassa menjadi bahan bakar. Hasil konversi biomassa ini dapat berupa biogas, bioetanol, biodiesel, arang dan sebagainya. Bioetanol dan biodiesel dalam jangka panjang diharapkan dapat digunakan sebagai pengganti bahan bakar minyak (Megawati, 2007).

Bioetanol dapat dibuat dari biomassa berbasis pati atau berbasis lignoselulosa. Namun biomassa berbasis pati umumnya dimanfaatkan sebagai makanan atau pakan, sehingga pemanfaatannya sebagai bahan baku bioetanol dapat mengganggu penyediaan makanan atau pakan. Oleh karena itu, pemanfaatan biomassa berbasis lignoselulosa perlu dikembangkan. Contoh biomassa berbasis lignoselulosa adalah kayu, tongkol, bonggol dan lain sebagainya.

Etanol banyak digunakan sebagai bahan bakar cair nabati. Etanol adalah alkohol yang didapat dari fermentasi bahanbahan yang mengandung gula, pati atau selulosa. Etanol merupakan bahan yang sangat penting karena merupakan bahan bakar cair dari sumber yang dapat diperbaharui (bioetanol). Bioetanol, tidak seperti bensin, merupakan bahan bakar oksigenat yang mengandung $35 \%$ oksigen yang dapat mereduksi partikulat dan emisi $\mathrm{NO}_{\mathrm{x}}$ dari hasil pembakaran (Demirbas, 2005). Greer (2005) menyatakan bahwa bioetanol dapat digunakan sebagai substitusi sebagian ataupun keseluruhan bahan bakar bensin. Pencampuran bioetanol dengan bensin dapat menaikkan angka oktan pada bahan bakar itu. Bensin memiliki angka oktan kurang dari 90. Penambahan etanol ke dalam bensin sebanyak $10 \%$ akan menaikkan angka oktan pada kisaran angka 110, sementara etanol murni memiliki angka oktan 112 (Wheals dkk., 1999). Penggunaan bioetanol sebagai bahan bakar akan menimbulkan gas berbahaya hasil pembakaran relatif lebih rendah daripada penggunaan bensin sebagai bahan bakar.

Manfaat pemakaian bioetanol di Indonesia yaitu memperbesar basis sumber daya bahan bakar cair, mengurangi impor bahan bakar minyak, menguatkan security of supply bahan bakar, meningkatkan kesempatan kerja, berpotensi mengurangi ketimpangan pendapatan individu dan antar daerah, meningkatkan kemampuan nasional dalam teknologi pertanian dan industri, mengurangi kecenderungan pemanasan global dan pencemaran udara (bahan bakar ramah lingkungan) serta berpotensi mendorong ekspor komoditi baru (Martono dan Sasongko, 2007).

Menurut Faith dkk. (1975), bioetanol dapat dibuat dari berbagai bahan baku, seperti gas hidrokarbon, bahan-bahan yang mengandung sakarosa (tebu, tetes, gula biet), bahan-bahan yang mengandung pati (ubi kayu, jagung, beras), maupun bahan-bahan yang mengandung selulosa (kayu, limbah pertanian, dan lain sebagainya).

Indonesia mempunyai potensi yang sangat besar untuk menghasilkan bioetanol mengingat bahan bakar nabati ini dapat memanfaatkan kondisi geografis dan sumber bahan baku dari berbagai tanaman yang tersedia di Indonesia. Salah satu tanaman yang dapat diproses menjadi bioetanol adalah tanaman pisang. Hampir di setiap tempat di Indonesia dapat dengan mudah ditemukan tanaman pisang. Semua bagian tumbuhan pisang dapat diolah dan dimanfaatkan khususnya sebagai bahan makanan. Bagian tumbuhan pisang yang tidak banyak digunakan untuk bahan makanan adalah bonggol atau batang pohon pisang. Jumlah produksi bonggol pisang di Indonesia mencapai 107,5 Mton per tahun. Selulosa yang terkandung dalam bonggol 
pisang mencapai $58,89 \%$, dan dapat diubah menjadi etanol melalui proses biologi dan kimia (biokimia).

Studi ini bertujuan mencari kondisi optimum dalam pembuatan bioetanol dari bonggol pisang dengan tujuan utama mencari pengaruh perbandingan berat padatan dan waktu hidrolisis terhadap glukosa terbentuk.

\section{Teori Dasar}

Senyawa karbohidrat dalam bentuk glukosa sudah lama dipakai sebagai bahan baku pembuatan etanol untuk kebutuhan industri makanan, kosmetik dan obat-obatan. Senyawa karbohidrat ini dapat ditemukan pada jagung, singkong, dan tetes tebu. Sedangkan sumber polisakarida tinggi dalam bentuk lignoselulosa relatif belum banyak diteliti untuk menghasilkan etanol. Senyawa selulosa tersebut memiliki potensi untuk diproses menjadi etanol. Penggunaan lignoselulosa sebagai bahan baku untuk memproduksi etanol dapat menurunkan biaya produksi dari segi harga bahan baku dibandingkan penggunaan gula dan jagung sebagai bahan baku (Wheals dkk., 1999).

Untuk mengubah selulosa menjadi glukosa (gula) diperlukan proses hidrolisis dengan bantuan asam, misalnya asam sulfat $\left(\mathrm{H}_{2} \mathrm{SO}_{4}\right)$, sedangkan untuk mengubah gula menjadi etanol dipergunakan ragi Saccharomyces cereviceae.

Reaksi hidrolisa selulosa menjadi glukosa sebagai berikut :

$$
\left(\mathrm{C}_{6} \mathrm{II}_{10} \mathrm{O}_{9}\right)_{\mathrm{a}} \text { : } \mathrm{n} \mathrm{II}_{2} \mathrm{O} \longrightarrow \mathrm{n} \mathrm{C}_{6} \mathrm{II}_{12} \mathrm{O}_{6}
$$

Pemilihan metode proses hidrolisis didasarkan pada jenis bahan baku dan perlakuan proses fermentasi yang akan dijalankan. Menurut Badger (2002) terdapat dua jenis proses hidrolisis yang dapat dijalankan, yaitu hidrolisis enzim dan hidrolisis kimiawi.

Proses hidrolisis kimiawi memiliki banyak keuntungan, yaitu biaya yang dibutuhkan relatif murah, karena harga bahan kimia yang dipakai lebih murah dibandingkan harga enzim. Selain itu, proses hidrolisis enzim membutuhkan waktu berhari-hari sedangkan hidrolisis kimiawi hanya memerlukan waktu yang relatif lebih cepat (Taherzadeh dkk., 1997; Palmqvist dan Hahn-Hagerdal, 2000). Bahan kimia yang dapat dipakai untuk memecah rantai polimer pada selulosa dan hemiselulosa adalah larutan asam, baik larutan asam pekat ataupun larutan asam encer. Larutan asam yang dapat digunakan ialah asam sulfat dan asam klorida.

Proses hidrolisis lignoselulosa dengan asam encer pernah dicobakan pada proses Scholler dalam reaktor tangki berpengaduk dengan kondisi operasi; konsentrasi asam sulfat $0,5 \%$, tekanan $11-12$ bar dan selama 45 menit. Hemiselulosa sebanyak $80 \% \mathrm{w} / \mathrm{w}$ dapat terhidrolisis pada suhu di bawah 200 ${ }^{\circ} \mathrm{C}$ tetapi konversi maksimal dicapai pada suhu di atas $220^{\circ} \mathrm{C}$ (Taherzadeh dkk., 1997). Proses hidrolisis pada suhu di atas $220{ }^{\circ} \mathrm{C}$ mengakibatkan terbentuknya senyawa racun bagi pertumbuhan mikroorganisme di dalam proses fermentasi. Senyawa-senyawa kimia yang bersifat racun tersebut ialah jenis senyawa asam karboksilat, senyawa furan dan senyawa fenol.

Lenihan dkk. (2009) melakukan penelitian hidrolisis kulit kentang dengan menggunakan asam fosfat encer pada suhu $135{ }^{\circ} \mathrm{C}$ selama 8 menit menggunakan asam fosfat $10 \%(\mathrm{~b} / \mathrm{b})$ dengan perolehan gula keseluruhan sebesar 82,5\% dan 55,2 g gula/100 g kulit kentang kering.

Pada penelitian sebelumnya, Gusmarwani dkk. (2009) telah meneliti pengaruh suhu pada hidrolisis bonggol pisang dengan katalis asam sulfat dengan suhu optimal yang didapat pada $120{ }^{\circ} \mathrm{C}$, waktu optimal 70 menit dengan hasil gula keseluruhan 7566,33 mg/100 mL sampel.

\section{Metodologi}

Bonggol pisang yang digunakan dalam penelitian ini merupakan campuran dari berbagai jenis tanaman pisang yang telah dibersihkan dari kotoran dan sisa akar yang melekat pada kulit bonggol pisang.

$$
\text { Percobaan diawali dengan }
$$

memasukkan $160 \mathrm{~g}$ bonggol pisang kering yang telah dipotong kecil seukuran beras dengan kadar air 13,68\% kandungan hemiselulosa sebesar $43,49 \%$, kadar selulosa $15,4 \%$ dan kadar lignin sebesar 10,3\%, ke dalam reaktor (autoclave) yang berdiameter $14 \mathrm{~cm}$ dan tinggi $12,5 \mathrm{~cm}$, disusul dengan menambahkan $1000 \mathrm{~mL}$ aquades dan $10 \mathrm{~mL}$ asam sulfat pekat p.a. Kemudian reaktor ditutup dengan sempurna dan pemanas serta motor penggoncang dinyalakan. Selama reaksi berlangsung suhu akan naik terus dan saat mencapai suhu $120{ }^{\circ} \mathrm{C}$ suhu dijaga konstan. Waktu nol dicatat pada saat pertama kali campuran mencapai suhu 120 
${ }^{\circ} \mathrm{C}$ dan dianggap reaksi berlangsung secara isotermal. Pengambilan sampel dilakukan setiap 10 menit sampai waktu 90 menit tercapai. Selanjutnya konsentrasi glukosa dalam sampel dianalisis dengan metode Lane and Eynon. Percobaan diulangi untuk berat bonggol yang berbeda sehingga didapat hasil percobaan untuk variasi perbandingan berat padatan:air dari 1:6,25, 1:5,88, 1:5,55, 1:5,25, $1: 5,1: 4,75,1: 4,54$, dan $1: 4,375$.

\section{Hasil dan Pembahasan}

Hasil percobaan dapat dilihat pada Tabel dan Gambar 1-8 berikut ini. Dari Tabel 1 dan Gambar 1-8 dapat dilihat bahwa semakin kecil perbandingan padatan:air, glukosa yang didapatkan semakin banyak. Gambar 1 memperlihatkan pada perbandingan padatan:air 1:6,25 gula pereduksi yang didapatkan cenderung mengalami kenaikan sampai dengan waktu reaksi 80 menit. Sedangkan pada waktu di atas 80 menit kecenderungan kadar gula pereduksi yang didapatkan mengalami penurunan Hal ini disebabkan karena pada waktu kurang dari 0-80 menit glukosa yang semula belum banyak terbentuk mulai banyak terbentuk hingga hasil maksimal pada waktu reaksi 80 menit. Pada waktu rekasi lebih dari 80 menit, sebagian glukosa rusak karena reaksi lanjut. Hal ini sama untuk perbandingan padatan:air 1:4,34 seperti yang ditunjukkan oleh Gambar 8. Perbedaannya terletak pada kadar glukosa maksimal yang didapat. Pada perbandingan 1:6,25 kadar gula pereduksi maksimal yang didapat 9373,77 mg/100 mL, sedangkan pada perbandingan 1:4,34 kadar gula pereduksi yang didapat 7679,46 mg/100 mL.

Pada Gambar 2 didapatkan kecenderungan kadar gula pereduksi yang rendah pada awal reaksi hingga menit ke-20. Setelah menit ke-20 hingga menit ke-80 mengalami kenaikan, dan cenderung menurun pada waktu reaksi di atas 80 menit. Pada Gambar 3, Gambar 7, dan Gambar 8 kecenderungan yang terlihat adalah pada awal reaksi hingga menit ke-10 atau 20

Tabel 1. Kadar Glukosa Sampel (Mg/100ml) pada Berbagai Perbandingan Padatan:Air (Suhu $120^{\circ} \mathrm{C}, 1000 \mathrm{~mL}$ Aquades, $10 \mathrm{~mL}$ Asam Sulfat)

\begin{tabular}{cccccccccccc}
\hline \multirow{3}{*}{ No } & Padatan & \multicolumn{8}{c}{ Kadar glukosa $(\mathrm{mg} / 100 \mathrm{~mL}$ ) pada waktu reaksi $0-90$ menit } \\
& :Air & 0 & 10 & 20 & 30 & 40 & 50 & 60 & 70 & 80 & 90 \\
\hline 1 & $1: 6.25$ & 0.00 & 0 & 4403 & 6701 & 7764 & 7764 & 8903 & 8782 & 9374 & 8438 \\
2 & $1: 5.88$ & 0.00 & 0 & 0 & 0 & 4655 & 5486 & 6550 & 7034 & 7262 & 7173 \\
3 & $1: 5.55$ & 0.00 & 0 & 3986 & 4951 & 5639 & 6912 & 8599 & 9369 & 9369 & 9642 \\
4 & $1: 5.26$ & 0.00 & 0 & 7709 & 9599 & 9938 & 10409 & 10614 & 10084 & 10286 & 9986 \\
5 & $1: 5.00$ & 0.00 & 4530 & 4558 & 8703 & 8997 & 10286 & 11543 & 12836 & 13080 & 10910 \\
6 & $1: 4.76$ & 0.00 & 0 & 4184 & 4706 & 7150 & 8265 & 9228 & 9584 & 10719 & 12757 \\
7 & $1: 4.54$ & 0.00 & 0 & 0 & 4770 & 6528 & 7691 & 9094 & 10719 & 10719 & 11026 \\
8 & $1: 4.34$ & 0.00 & 0 & 0 & 4491 & 5639 & 6724 & 7682 & 7900 & 7679 & 10359 \\
\hline
\end{tabular}

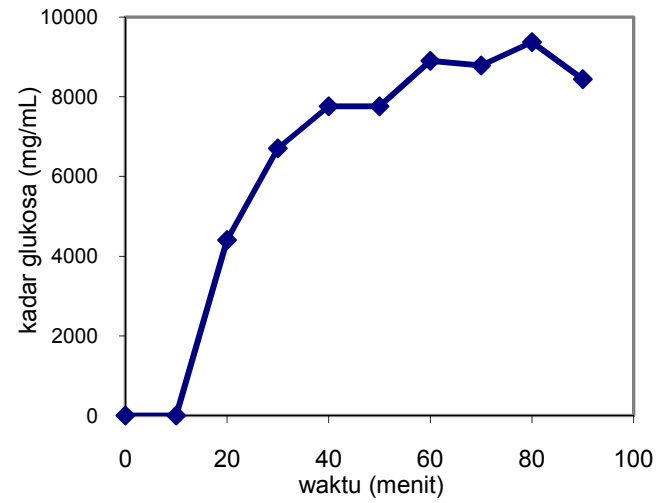

Gambar 1. Kadar glukosa sampel $(\mathrm{mg} / 100 \mathrm{~mL})$ pada perbandingan padatan : air $=1: 6,25$

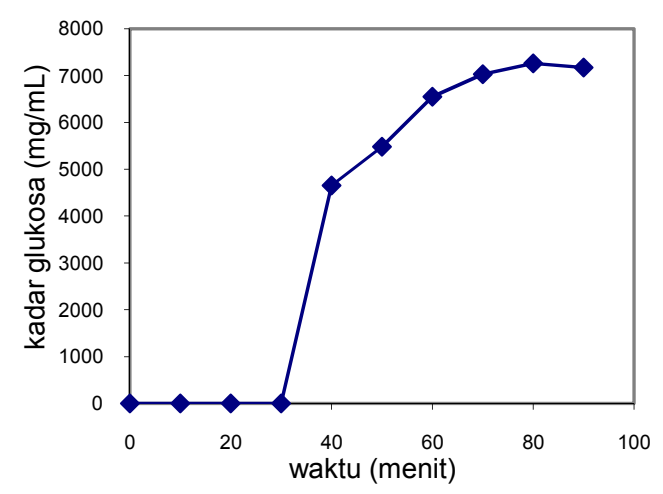

Gambar 2. Kadar glukosa sampel $(\mathrm{mg} / 100 \mathrm{~mL})$ pada perbandingan padatan:air $=1: 5,88$ 


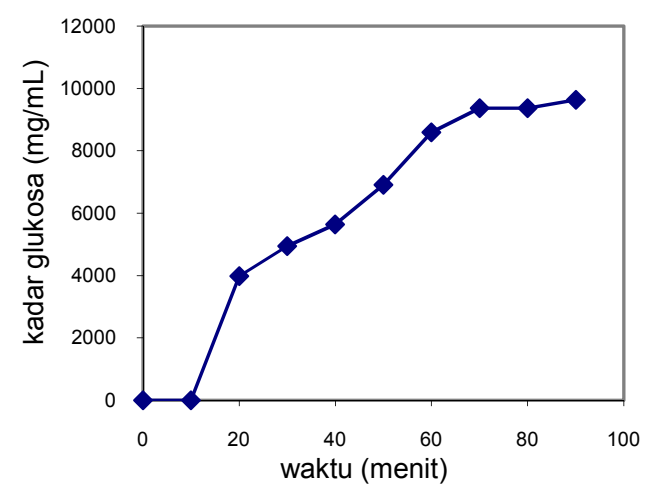

Gambar 3. Kadar glukosa sampel (mg/100mL) pada perbandingan padatan:air = 1:5.55

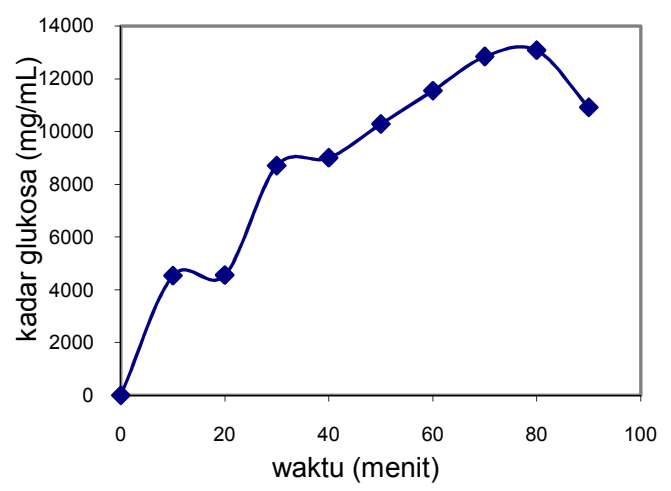

Gambar 5. Kadar glukosa sampel (mg/100mL) pada perbandingan padatan:air $=$ 1:5.00

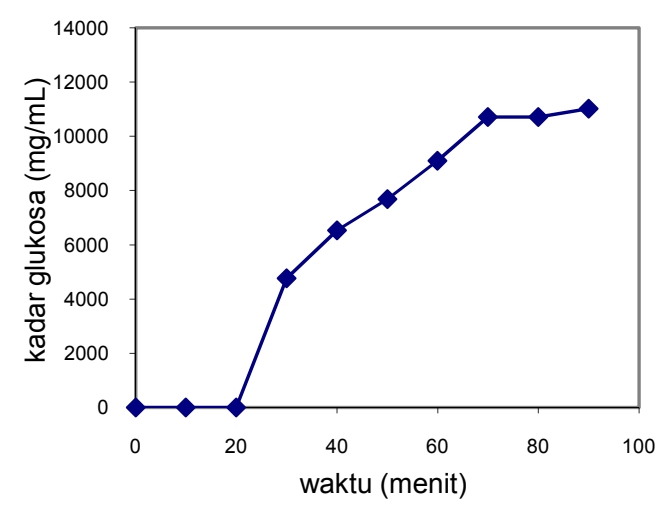

Gambar 7. Kadar glukosa sampel $(\mathrm{mg} / 100 \mathrm{~mL})$ pada perbandingan padatan:air $=1: 4.54$

kadar gula pereduksi yang didapat masih rendah. Hal ini disebabkan pada menit-menit awal reaksi, selulosa yang terkandung dalam

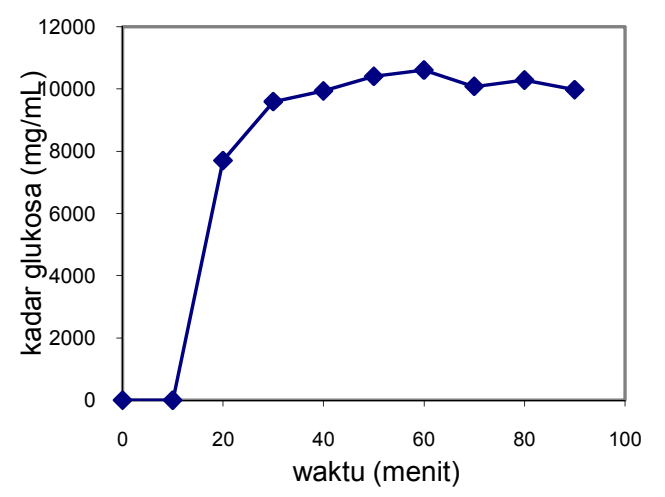

Gambar 4. Kadar glukosa sampel ( $\mathrm{mg} / 100 \mathrm{~mL})$ pada perbandingan padatan:air $=$ 1:5.26

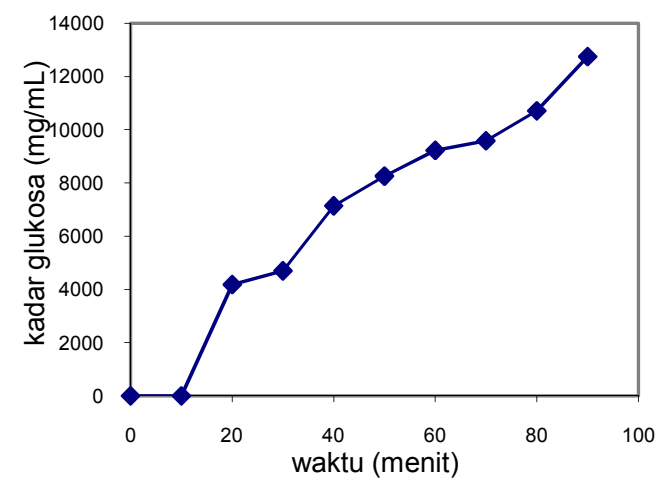

Gambar 6. Kadar glukosa sampel (mg/100mL) pada perbandingan padatan:air $=1: 4.76$

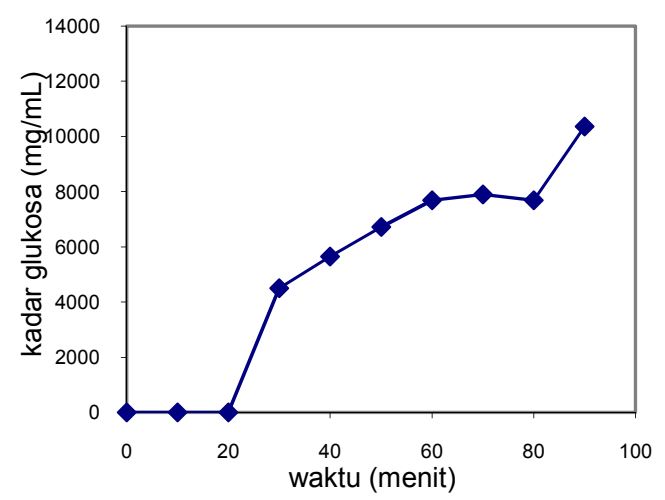

Gambar 8. Kadar glukosa sampel (mg/100mL) pada perbandingan padatan:air $=1: 4.34$

bahan belum banyak bereaksi sehingga gula pereduksi yang didapat masih rendah, sedangkan pada waktu reaksi di atas 20 
menit mengalami kecenderungan naiknya kadar gula pereduksi yang didapat. Hal ini disebabkan masih berlangsungnya reaksi hidrolisis dari selulosa yang ada dalam bahan menjadi gula. Hal yang perlu diperhatikan adalah meskipun masih mengalami kecenderungan kenaikan kadar gula pereduksi yang didapat, tetapi jika dibandingkan dengan gula pereduksi yang didapat pada perbandingan padatan:air 1:5 dengan waktu reaksi 80 menit seperti yang ditunjukkan Gambar 5, hasil gula pereduksi lebih banyak pada kondisi reaksi ini. Selain hal tersebut di atas, pada perbandingan padatan:air kurang dari 1:5, yang berarti semakin banyak jumlah padatan yang ada dalam larutan menyebabkan kurang sempurnanya kontak antarpereaksi sehingga hasil reaksi kurang optimal. Pertimbangan tersebut yang mendasari kesimpulan bahwa kondisi operasi yang terbaik dicapai pada perbandingan padatan:air $=1: 5$ dengan waktu reaksi 80 menit dengan jumlah glukosa yang didapatkan 13,080 g/100mL.

\section{Kesimpulan}

Kesimpulan yang dapat diambil adalah: glukosa terbanyak yang dapat terambil sebesar $13,080 \mathrm{~g} / 100 \mathrm{~mL}$ pada suhu $120{ }^{\circ} \mathrm{C}$, yaitu pada perbandingan padatan:air 1:5, dan waktu reaksi 80 menit.

\section{Ucapan Terima Kasih}

Pada kesempatan ini kami mengucapkan terimakasih kepada:

1. Jurusan Teknik Kimia Universitas Gadjah Mada Yogyakarta yang telah mengijinkan kami untuk melakukan penelitian di laboratorium pemisahan bahan (OTK).

2. Direktorat Penelitian dan Pengabdian kepada Masyarakat (DP2M) Ditjen Pendidikan Tinggi Departemen Pendidikan Nasional melalui program Hibah Penelitian Antar Perguruan Tinggi (Hibah Pekerti) pendanaan tahun anggaran 2009 yang telah membiayai penelitian ini.

\section{Daftar Pustaka}

Badger, P. C., Ethanol from Cellulose: A General Review, in Trends in New Crops and New Uses, Janick, J; Whipkey, A., Eds., ASHS Press, 2002, 17-21.
Demirbas, A., Bioethanol from Cellulosic Material : A Renewable Motor Fuel from Biomass, Energy Source, 2005, Vol. 27, 327337.

Faith, W. L.; Keyes D. B.; Clark, R. L., Industrial Chemicals, 3rd ed., John Wiley and Sons Inc., New York, 1975.

Gusmarwani, S. R.; Budi, M.S.P.; Sediawan, W.B.; Hidayat, M., Pengaruh Suhu Pada Hidrolisis Bonggol Pisang Dalam Rangka Pembuatan Bioetanol, Prosiding Seminar Tjipto Utomo 2009, hal B6 1-7, Bandung 2009.

Greer, D., Creating Cellulosic Ethanol: Spinning Straw into Fuel, BioCycle eNews Bulletin, May 2005, http://www.harvestcleanenergy.org (akses Juli 2008)

Lenihan, P.; Orozco A.; O'Neill E.; Ahmad, M.N.M; Rooney, D.W.; Walker, G.M., Dilute Acid Hydrolysis of Lignocellulosic Biomass, Chemical Engineering Journals, 2009, Vol. 156, 395-403.

Martono, B.; Sasongko, Prospek Pengembangan ubi Kayu sebagai Bahan Baku Bioetanol di Propinsi Daerah Istimewa Yogyakarta, Dinas Pertanian Propinsi DIY, www.distan.pemdadiy.go.id (akses Juli 2007).

Megawati, Etanol dari Lignoselulosa, Profesional, 2007, Vol. 1(5).

Palmqvist, E.; Hahn-Hagerdal, B. H., Fermentation of Lignocellulosic Hydrolysates. II: Inhibition and Detoxification, Bioresource Technology, 2000, Vol. 74(1), 25-33.

Taherzadeh, M. J.; Eklund, R.; Gustafsson, L.; Niklasson, C.; Liden, G., Characterization and Fermentation of Dilute-Acid Hydrolyzates from Wood, Industrial \& Engineering Chemistry Research, 1997, Vol. 36(11), 46594665.

Wheals, A. E.; Basso, L. C.; Alves, D. M.; Amorim, H. V., Fuel Ethanol after 25 Years, Trends Biotechnology, 1999, Vol. 17(12), 482-487. 